\title{
Neighborhood change and the role of environmental stewardship: a case study of green infrastructure for stormwater in the City of Portland, Oregon, USA
}

\author{
Vivek Shandas $^{1,2}$
}

\begin{abstract}
Throughout the history of cities, the ecological landscape has often been buried, removed, or taken for granted. A recent recognition that humans are part of the global ecosystem, and that human actions both cause and are affected by ecological change, brings with it an awareness of the value of nature in cities and of natural systems on which cities depend. The feedbacks between humans and their environment within an urban context can have profound implications for the growth of and change in cities, yet there is a limited understanding of the interactions between biophysical changes in cities and the implications of these changes on the quality of life for residents. The application of a coupled human and natural systems (CHANS) framework provides a timely and fruitful opportunity to enrich the theory, methods, and understanding of these feedbacks and interconnections. Here, I integrated biophysical and social dimensions relevant to managing urban stormwater by examining a case study of Portland, Oregon, USA. I used empirical data from a pre-post survey (2-yr span) of residents in eight urban neighborhoods to describe feedbacks and interactions between a localized biophysical change in the form of a large-scale decentralized stormwater program and the resulting changes in resident's perceptions in neighborhoods undergoing rapid change. My findings corroborate earlier findings suggesting that people with higher income and education levels are more likely to participate in stewardship actions. The results also suggest an overall and initial negative perception of neighborhoods facilities and services immediately following the construction of decentralized stormwater facilities, but conversely, high levels of anticipation for their construction. By describing these findings through a CHANS framework, I make explicit the importance of integrating scientific understanding, governance efforts, and human behaviors to address acute urban environmental challenges.
\end{abstract}

Key Words: CHANS; stewardship; stormwater management; urban

\section{INTRODUCTION}

With more than one-half of the global population living in urban areas, and with accounts that this number will exceed $70 \%$ by 2050 (United Nations 2008), people living in cities will affect and be affected by the systems on which they depend. Even with cities covering $<3 \%$ of the Earth's land surface, their effect on global ecosystems is persistent and profound (Vitousek et al. 1997). However, cities vary in form and development patterns, and the people living in them are increasingly responsible for managing their growth and change. While scholars of urban systems and planning increasingly agree that addressing appropriate scales of intervention is an essential part of effective policy action (MacLeod and Goodwin 1999, Furlong 2010), an understanding of how coupled human and natural systems (CHANS) might improve decision making efforts in cities is still missing. Important questions include: What are the indirect effects of policy actions that affect the coupling of social and ecological systems? How do emergent properties of urban systems interact with biophysical conditions to affect the quality of life for urban residents? And more specifically: How do attempts to restore ecosystem services in cities reduce (or exacerbate) vulnerabilities of CHANS? Addressing these and related questions will be essential as cities prepare to face greater populations, increasing demand for natural resources, and emerging effects of climate change.

An immediate opportunity for a better understanding of the coupling of human and natural systems across scales is available by examining local actions on one of the current primary environmental challenges: climate-change-related destabilization. At the global scale, an increase in temperature is having profound implications for local conditions through increased rainfall, extended drought, and extreme weather events. While climate change is having and will increasingly affect cities and their surrounding areas, urban scholars are beginning to recognize the need to take local action to reduce many of the anticipated harmful effects on urban systems and communities (Brody et al. 2008, Wheeler 2008, Bassett and Shandas 2010). Although the literature on effective policy actions suggests that improvements are easier when made at the neighborhood, town, city, or metropolitan level, i.e., where policy makers are closer to their citizens, than at the national government level (Chapin et al. 2010), there is currently a limited understanding of the role of citizens in contributing to climate-proofing neighborhoods for the emerging challenges associated with climate-induced changes. Moreover, without an explicit understanding of the coupling of human and natural systems within the urban context, isolated, static, and often fragmented scientific analyses and institutional processes will continue to be used to address the environmental challenges facing cities and their residents.

Here, I present empirical evidence about changes in human perceptions as a result of a large-scale green infrastructure intervention that aims to divert stormwater (a major challenge associated with climate extremes) from the traditional underground sewer and pipe system. I focus on the implications of physical modifications in the stormwater system at the neighborhood scale on human perceptions and behavior. I use as a case study the Portland Metropolitan region (Oregon, USA) because it has one of the largest mature green stormwater systems in the United States. I ask two overarching research questions: (1) How do changes in the biophysical landscape of stormwater management affect perceptions of neighborhood quality and 
services? (2) What demographic factors contribute to the likelihood of residents engaging in stewardship behaviors that sustain the green stormwater infrastructure? The first question supports my interest in contributing to the CHANS discourse by linking biophysical changes and human perceptions. With the second question, I aim to assess the likelihood of changing human behavior in the midst of a large-scale change in neighborhood infrastructure. I begin by describing the theoretical dimensions germane to environmental behavior, and follow with a conceptual framework that identifies specific mechanisms for coupling human and natural systems.

\section{Managing urban stormwater and environmental behavior}

Urban stormwater management is one formidable consequence of climate change because of an increase in precipitation onto the impervious surfaces that define cities in much of the Western Hemisphere. Indeed, increases in storm size and frequency have led to massive social, economic, and ecological effects; for example, Hurricane Sandy in 2012 caused stormwater-related damage between USD $\$ 30$ and 50 billion on the U.S. eastern seaboard (Wall Street Journal 2012). In many regions of the United States, climate predictions suggest the occurrence of wetter winters and increases in total annual stormwater flows (Dulière et al. 2011). Because of the extensive area of impervious surfaces in cities coupled with predictions of greater intensity, frequency, and magnitude of storms, local governments are taking action to mitigate potential flooding hazards by using "green infrastructure" approaches to managing stormwater.

Some examples of green infrastructure currently implemented and under consideration by city managers include rain gardens and eco-roofs at household scales, bio-retention and detention facilities at neighborhood scales, and increasing the urban tree canopy at regional scales (United States Environmental Protection Agency 2007). These large-scale investments are changing the biophysical landscape and are altering the visible landscape of cities (National Research Council 2009). Unlike their grey counterparts, which include pipes, culverts, and other underground systems for directing stormwater, green techniques change the visible landscape by removing impervious surfaces, bringing the collection of stormwater to the surface, increasing the amount of vegetation on roadsides, and altering the road networks. Green stormwater facilities largely involve retrofits to existing underground pipe networks and often contain trees, shrubs, flowering plants, cement dams, information signage, and art features. As a result, they have the potential to affect the quality of life for citizens living near these facilities.

As many cities undergo physical transformations in their stormwater systems, assessing the feedbacks to the relevant social systems offers an immediate and potentially informative perspective for understanding the coupling of human and natural systems. In this context, feedbacks are social responses to biophysical changes and may offer clues about a community's capacity for or interest in maintaining the modified landscapes. I posit that feedbacks between neighborhood change and social response are mediated through frequent, if not daily, access and contact with natural features such as trees, shrubs, and bare soil. Before the creation of visible stormwater systems, stormwater infrastructure was invisible and sealed by impervious surfaces and an underground pipe system. As illustrated in earlier studies, the integration of nature into neighborhoods has the potential for raising awareness of neighborhood conditions, including those of the biophysical landscape and the local ecosystem (Hough 2004, Dale 2009, Beatley 2011). Behavioral science theories further suggest that increases in awareness of and frequent access to nature can contribute to environmental learning and an environmental ethic (Ryan 2005), an idea that coincides with transformative and experiential learning theories (Mezirow 1997, Jarvis 2009), which in turn can coalesce into action to improve local environments.

A related theory also recognizes that increases in environmental knowledge and awareness do not directly lead to proenvironmental behavior such as stewardship (Kreutzwiser et al. 2011). Since the 1970s, numerous theories have provided explanations for this disconnect between linear models of knowledge and action, environmentally directed or otherwise. The theory of reasoned action (Fishbein and Ajzen 1975) and the theory of planned behavior (Ajzen and Fishbein 1980) are two prominent theories that describe a combination of specific behaviors, rational attitudes, and normative pressures as directly influencing people's intentions to act.

Unlike the aforementioned theories that focus on the individual as the sole agent of change, socially based theories such as the norm-activation model describe moral or social norms and obligations that incite specific behaviors. Such social practice or socially normative theories emphasize the collective approach and the importance of enablers or barriers related to infrastructure, economic incentives, and social or cultural factors (Blake 1999, Kollmus and Agyeman 2002). Socially based approaches call for policy interventions that shape practices of daily life into sustainable routines (Reckwitz 2002, Shove 2010). In these approaches, neighborhoods and institutions serve as mechanisms for enabling or preventing actions because they create a set of norms by which actions are deemed socially acceptable.

Although individual and socially induced theories of action may affect the likelihood of environmental stewardship in different ways, these are not linear relationships, and a rich body of literature (e.g., Liu et al 2007, Alberti 2008) suggests the need to examine feedbacks and mechanisms that mediate individual or collective responses to environmental change. To date, few studies have explored the relationship between biophysical change, human perception, and the feedback mechanisms that induce stewardship, mainly because of the complexity of the humanenvironment interaction. Here, I offer a framework for illustrating feedbacks between the biophysical and social systems. I employ this framework in the form of a conceptual diagram that integrates multiple subsystems within an urban environment: the biophysical landscape, individually directed approaches to actions, and social responses (Fig. 1).

The conceptual diagram explicitly describes the role of human perception and framing with regard to the biophysical landscape. I develop explicit linkages that connect the structure and function of the emerging stormwater landscape with individual perceptions and social and institutional responses. Unlike in other feedback diagrams (e.g., Alberti et al. 2003, Grimm and Redman 2004, Pickett et al. 2009), I posit that the structure and function of the stormwater landscape directly affects human perceptions, understandings, and values regarding the immediate physical 
Fig. 1. Conceptual model coupling the biophysical landscape with the human and social system. Adapted from Shandas et al. (2014).

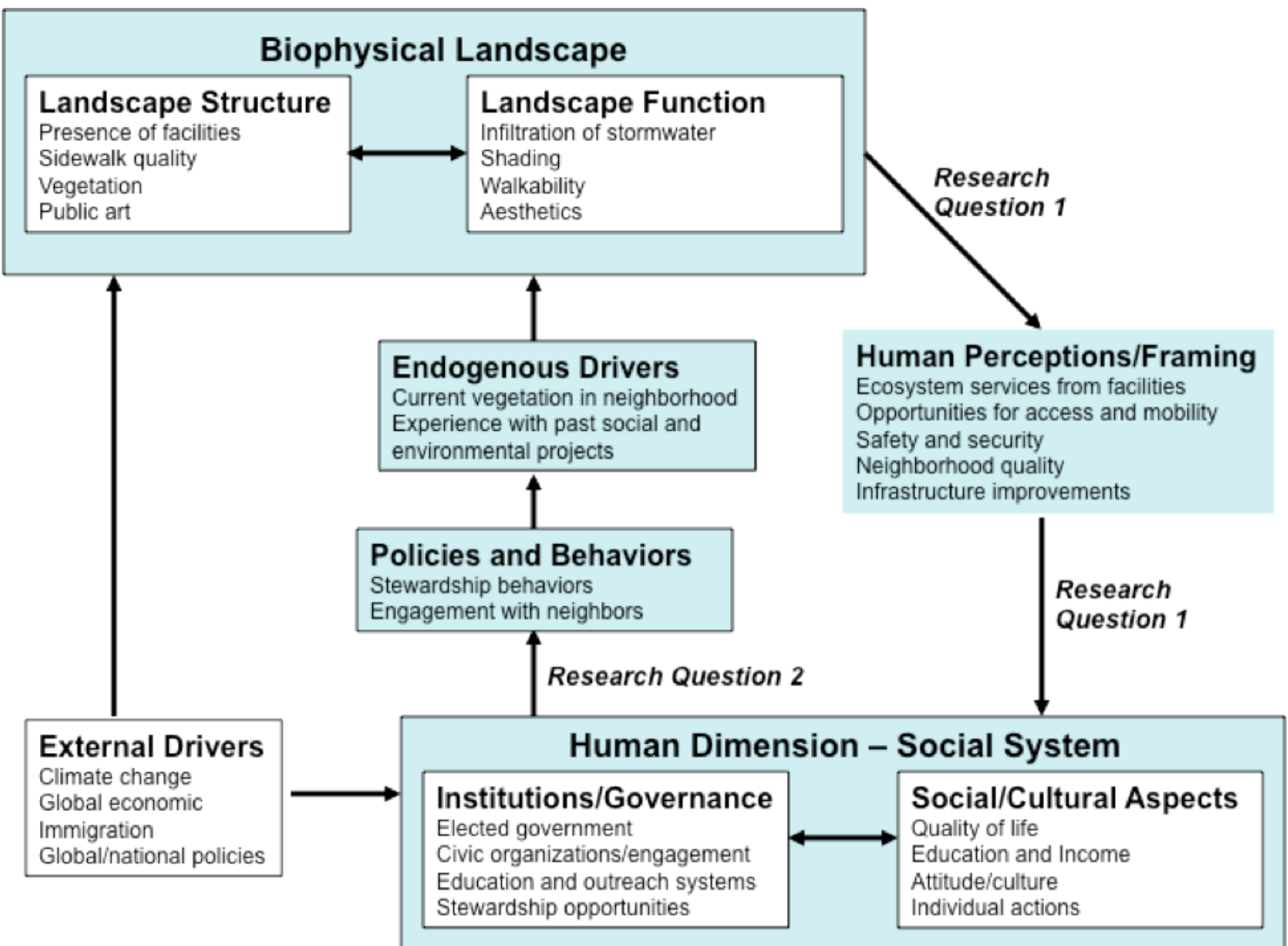

environment (research question 1). These perceptions, understandings, and values are the mechanisms for inducing individual, social, and institutional actions. These institutional and social-cultural dimensions are illustrated as looping back to affect policies and behaviors (research question 2). Endogenous factors such as current vegetation in the neighborhood or past experiences further modify these behaviors, thereby affecting the likelihood of stewardship behavior that changes the biophysical landscape. I also recognize that cities are open systems that are affected by external drivers such as climate change, increasing population, and state and federal planning efforts, to which local actions must respond. Only the shaded boxes are of direct interest for my purposes, and I do not explicitly study external drivers here. In terms of urban stormwater management, these scaledependent feedbacks allow the study of the role of biophysical change as a precursor to shifts in perceptions, policies, and stewardship actions.

\section{METHODS}

Case study

I apply the framework (Fig. 1) to a case study of a large-scale green infrastructure project underway in the City of Portland, Oregon, USA, which is located in the U.S. Pacific Northwest. With an average of $94 \mathrm{~cm} / \mathrm{yr}$ of rainfall, Portland's rain-fed landscape has long been affected by stormwater challenges.
Portland offers several opportunities for assessing the feedbacks proposed in the framework. The green infrastructure project, called the Tabor to River (T2R) program (http://www. portlandoregon.gov/BES/47591), covers $5.67 \mathrm{~km}^{2}$ in the southeast quadrant of the city. The project aims to improve watershed function and sewer stormwater capacity through several physical changes to the landscape, including: an extensive green infrastructure network of 500 vegetated stormwater facilities in the public right-of-way, the addition of $>100$ private stormwater facilities, the planting of 3500 trees, and the repair or replacement of $266 \mathrm{~km}$ of sewer pipe. The program also aims to engage community members in areas undergoing change by delivering educational materials and soliciting input through workshops. With the extensiveness of infrastructure change, the $\mathrm{T} 2 \mathrm{R}$ program offers a meaningful case through which to understand the coupling of human and natural systems within an urban landscape, as well as the qualities of a neighborhood that are affected by the introduction of green infrastructure.

In addition, as in other U.S. cities, Portland's residents exhibit strong distrust of government. The distrust is likely due in part to two lawsuits against the city, the first in 1989, when the U.S. Environmental Protection Agency fined the City's Bureau of Environmental Services (BES), which is responsible for stormwater management, for 22 violations of the Toxic Substances Control Act, and another in 1993, when the Northwest 
Table 1. General characteristics of the six treatment and two control neighborhoods.

\begin{tabular}{|c|c|c|c|c|c|}
\hline Neighborhood & $\begin{array}{l}\text { Number of } \\
\text { parcels }\end{array}$ & $\begin{array}{l}\text { Single family } \\
\text { residences }(\%)\end{array}$ & $\begin{array}{l}\text { Homeowners } \\
(\%)\end{array}$ & $\begin{array}{c}\text { Median } \\
\text { income (USD) }\end{array}$ & Neigbhorhood description \\
\hline 1 & 236 & 53.40 & 49.00 & $\$ 43,145$ & $\begin{array}{c}\text { Extensive program and project outreach; } \\
\text { stormwater green infrastructure } \\
\text { implementation }\end{array}$ \\
\hline 2 & 707 & 81.60 & 55.80 & $\$ 42,044$ & $\begin{array}{c}\text { Extensive program and project outreach; } \\
\text { stormwater green infrastructure } \\
\text { implementation }\end{array}$ \\
\hline 3 & 374 & 92.20 & 61.50 & $\$ 40,219$ & $\begin{array}{l}\text { Extensive program; limited project outreach; no } \\
\text { implementation }\end{array}$ \\
\hline 4 & 339 & 88.20 & 70.30 & $\$ 45,000$ & $\begin{array}{l}\text { Extensive program; limited project outreach; no } \\
\text { implementation }\end{array}$ \\
\hline 5 & 189 & 95.20 & 69.20 & $\$ 50,909$ & Extensive program; no project outreach \\
\hline 6 & 141 & 97.90 & 71.70 & $\$ 50,125$ & Extensive program; no project outreach \\
\hline All treatment neighborhoods & 331 & 84.80 & 62.90 & $\$ 45,240$ & \\
\hline 7 (control) & 332 & 73.80 & 59.20 & $\$ 46,033$ & No outreach or implementation \\
\hline 8 (control) & 316 & 96.50 & 68.10 & $\$ 46,667$ & No outreach or implementation \\
\hline All neighborhoods & 2634 & 84.10 & 59.40 & $\$ 45,240$ & \\
\hline
\end{tabular}

Environmental Advocates, a local nonprofit, sued the city for violation of the Clean Water Act. Based on these and other challenges, the City of Portland pursued an approach to stormwater management that rivals traditional sewer and pipe systems, whose purpose is to convey water away from city streets as quickly as possible. This nontraditional approach, called "green streets" or "sustainable stormwater" by the City (City of Portland 2007), is part of a broader watershed management plan that attempts to address the degrading pipe infrastructure, engage citizens in stewardship efforts, and develop decentralized stormwater facilities that capture stormwater and infiltrate soils (http://www.portlandoregon.gov/bes/38965).

By using the City of Portland as an exemplar, I conduct a systematic examination and evaluation of the feedbacks across the biophysical and social components of a single geographic region. Through the examination of one geographic region in detail, I aim to retain the holistic and meaningful characteristics that illuminate feedbacks (Yin 2003) while identifying mechanisms for better management of the natural and social systems that, in this case, affect stormwater management.

\section{Research design}

The research design consists of an evaluation of the changes in social perceptions specific to the physical conditions in eight neighborhoods in the T2R area. The neighborhoods were selected based on the schedule of construction and comparable sociodemographic variables. I focused on 2634 single-family residential units within the $\mathrm{T} 2 \mathrm{R}$ project area. In the pre-post research design, two surveys were sent to all households in eight neighborhoods, one in May 2009 and another in May 2011 (human subjects approval \#111898). The first survey contained a question that asked respondents if the researchers could follow up with them based on their responses. Those who marked "yes" received the second survey in May 2011. For all eight neighborhoods in the study, the timing of the first survey preceded physical changes in stormwater facilities and any provision of educational materials. By the second survey, two of the neighborhoods (1 and 2) had undergone construction, whereas the others were in different stages of outreach. At the time of the second survey, 52 facilities had been installed in neighborhoods 1 and 2 of the T2R project area. Two of the eight neighborhoods were "controls" where there was neither outreach nor physical changes related to the installation of stormwater facilities. Based on City descriptions, each of the eight neighborhoods had one of the following characteristics: (1) had recently seen biophysical changes as part of the green infrastructure program; (2) had residents that received extensive educational materials about the stormwater facilities forthcoming coming to their neighborhood in the next year; (3) had residents that received less educational materials about forthcoming stormwater facilities, which were slated to undergo construction over the next two years in their neighborhood; and (4) had residents living outside the area, and did not receive any educational materials and would serve as control groups (Table 1). These characteristics provided the basis for creating four distinct neighborhoods types within the T2R project area. The pre-post research design allowed me to assess the extent to which the biophysical changes occurring to and educational materials provided for (if any) households created feedback that affected social perceptions and behaviors.

The use of publicly available demographic data for all survey neighborhoods ensured that the selection of neighborhoods varied by income, neighborhood density, land-use mix, and resident tenure, which are factors known to affect perceptions of and responses to neighborhood change (Cao et al. 2007, Connolly et al. 2014). The social and built conditions of the six T2R neighborhoods allowed for the selection of two additional comparable control neighborhoods, one located north (neighborhood 7) and one located south (neighborhood 8) of the $\mathrm{T} 2 \mathrm{R}$ project area.

Although the survey questions varied slightly between survey mailings, there were 28 questions divided into four sections: (1) awareness of the T2R stormwater program, (2) perceptions of the neighborhood and stormwater facilities, (3) understanding of and interest in stewarding stormwater facilities, and (4) demographics of the respondent. I assessed differences between each of the T2R neighborhoods and control areas, and to maintain anonymity, each survey was coded alpha-numerically based on the address 
of the potential respondent. To increase response rates, each household received an introductory postcard one week prior to the mailing of the survey and a reminder postcard one week after the surveys were received. I posted advertising about the survey in a local newspaper, and offered several prize drawings for those who returned the completed survey within three weeks.

\section{Analysis}

I used two methods to analyze the surveys. First, I used a difference of means calculation, which consisted of a simple subtraction of Likert scale responses to the same question posed in surveys 1 and 2 . Where I observed a similarity of variance in a response, I conducted a paired t-test analysis to assess the statistical significance of results. The difference in responses corresponded to two measures of neighborhood quality (perception of physical and social attributes and perception of services) identified based on ourmy understanding of the changes expected as part of the City's green infrastructure program (City of Portland 2010) and application of earlier literature on sense of place and neighborhood quality (Chavis and Wandersman 1990, Bonaiuto et al. 1999, Brown et al. 2003). Physical and social attributes included perceptions of safety, attractiveness, friendliness toward families, health, sociability, and walkability. The services included public art, biking facilities, street cleaning, community centers, parking, greenery and trees (open space), walking facilities, and neighborhood associations. I presumed that a difference between survey responses reflects changes in neighborhood perceptions. I hypothesized a larger change in perceptions of neighborhood quality and services in neighborhoods that had undergone changes in stormwater infrastructure than in those that had not. For example, consider the following survey question. Rate how well you believe your neighborhood provides parks and open space: (1) not at all, (2) very poorly, (3) poorly, (4) marginally, (5) well, (6) very well. If a participant indicated in the May 2011 survey that their neighborhood provided parks very well (a value of six), but had noted that parks were marginal (a value of four) in the May 2009 survey, then a positive (in this case +2 ) change in perception was ascribed to neighborhood parks and open space. Conversely, if the respondent provided a higher rating for parks in the initial than in the final survey, then the difference would indicate a negative change. This scoring system, which is consistent with standard survey analytics (Dillman 2007), provides a straightforward, quantitative approach to assessing the magnitude of changes of perceptions. Because respondents were the same from the first survey to the second, these responses are relative to their individualized perceptions.

Second, I used a series of step-wise linear ordinary least squares (OLS) regression models. Although the literature suggests a link between demographic variables and the likelihood of participating in environmental projects (see for example, Hough 2004, Cao et al. 2007, Connolly et al. 2014), less is known about the role of other factors such as prior experience with environmental projects and level of engagement with neighbors. Accordingly, I considered a number of variables that are expected to affect stewardship of stormwater facilities in the study neighborhoods. The regression analysis helped to address the question, What demographic characteristics help to explain interest in stewarding stormwater facilities in study neighborhoods? By including responses to demographic and other responses as independent variables, and scalar responses to the survey statement "I would be willing to participate in stormwater management in my neighborhood" as the dependent variable, I constructed an overall regression equation that describes the extent to which each factor helps or hinders the propensity to steward a facility. The independent variables for demographics were: income, age, education attainment, tenure in home, and renter/owner status. Other factors included: level of involvement in community and environmental activities, level of engagement with neighbors, involvement in city and regional community events, and current perceptions of the neighborhood (Appendix 1). I also developed two additional stepwise linear OLS models to evaluate only the role of income, and whether different factors mattered for those who had more or less money. I used two OLS regression models: one that included only those respondents who self-reported as earning $>\$ 75,000 \mathrm{USD} / \mathrm{yr}$, and one that included only those who self-reported as earning < $\$ 75,000$ USD/yr.

Before developing the regression models, I tested for multicollinearity between the selected variables using Pearson correlation and removed individual variables that had $r>0.7$, which is consistent with other social science techniques (Dillman et al. 2014). The stepwise regression model also selected for significant independent variables, removing redundancy in the regression models. By regressing individual perceptions of neighborhood conditions, demographics, and other survey responses, I identified specific characteristics of respondents that increased the probability of neighborhood stewardship of public stormwater facilities. My interest here is not to describe the specific probabilities for stewardship potential, but rather to use the results to assess general factors that would increase the probability for stewarding stormwater facilities within each of the study neighborhoods.

\section{RESULTS}

The response rate varied between the two surveys. Of the 2192 surveys that were successfully mailed to residents in May 2009 (survey 1 ), the response rate was $30 \%$ (650 responses). The second survey comprised a subset of 286 respondents from survey 1 and had a response rate of 46\% (132 responses) across all eight neighborhoods. Response rates varied among the neighborhoods from as low as $13 \%$ (neighborhood 8) to as high as $65 \%$ (neighborhood 7). The demographic profile of respondents was consistent with data obtained through the U.S. Census Bureau and consisted of $78 \%$ of respondents with Bachelor's degree or higher and $65 \%$ with an annual income $>\$ 50,000$ (USD). The age of respondents, which had the highest variance of all the demographic indicators considered, was between 25 and $64 \mathrm{yr}$, with a small proportion $(14 \%)>65$ yr old. I used both surveys to examine differences in responses over time, and employed regression analysis to predict the likelihood of stewardship only for the first survey.

\section{Changes in neighborhood perceptions}

The majority of the survey questions indicated a positive trend for perception of neighborhood quality (Table 2). A positive trend suggests that residents have an overall high and increasingly appreciative opinion of the neighborhood, whereas a negative result suggests a perception of decreasing neighborhood quality and services. The largest and statistically significant changes in 
Table 2. Resident's perceptions of neighborhood quality and services.

\begin{tabular}{|c|c|c|c|c|c|c|c|}
\hline \multirow[t]{2}{*}{$\begin{array}{c}\text { Characteristic } \\
\text { Item }\end{array}$} & \multicolumn{2}{|c|}{ All neighborhoods } & \multicolumn{5}{|c|}{ Neighborhood $\left(N^{\dagger}\right)$} \\
\hline & Survey $2^{\ddagger}$ & Survey $1^{\ddagger}$ & $\begin{array}{l}1 \text { and } 2 \\
\text { (35) }\end{array}$ & $\begin{array}{c}3 \text { and } 4 \\
\text { (37) }\end{array}$ & $\begin{array}{c}5 \text { and } 6 \\
\text { (18) }\end{array}$ & $\begin{array}{c}7 \text { and } 8 \\
(42)\end{array}$ & Overall trend \\
\hline \multicolumn{8}{|l|}{$\overline{\text { Quality }^{\S}}$} \\
\hline Safe (traffic) & $4.24 *$ & $4.07^{*}$ & $0.1^{*}$ & $0.78^{*}$ & 0.17 & 0.21 & 0.18 \\
\hline Safe (crime) & 4.76 & 4.69 & 0.06 & 0.4 & 0.17 & 0.1 & 0.07 \\
\hline Attractive & 4.93 & 4.86 & -0.03 & $0.53^{*}$ & 0 & 0.17 & 0.07 \\
\hline Family friendly & 4.88 & 4.82 & -0.13 & $0.7^{*}$ & 0.48 & -0.13 & 0.06 \\
\hline Healthy & 4.7 & 4.72 & -0.1 & $0.74 *$ & 0.07 & $-0.24^{*}$ & -0.02 \\
\hline Friendly or social & 4.98 & 5.04 & -0.29 & $0.52 *$ & 0.08 & $-0.23^{*}$ & -0.07 \\
\hline Walkable & $5.35^{*}$ & $5.55^{*}$ & $-0.39^{*}$ & $0.62 *$ & 0.16 & $-0.26^{*}$ & -0.2 \\
\hline \multicolumn{8}{|l|}{ Services } \\
\hline Public art & $3.78^{*}$ & $2.8^{*}$ & $1.31^{*}$ & $0.88^{*}$ & $0.81^{*}$ & $0.72 *$ & 0.98 \\
\hline Bicycling facilities & $5.22 *$ & $4.61^{*}$ & $0.37 *$ & $0.71 *$ & $0.58 *$ & $0.67^{*}$ & 0.61 \\
\hline Street cleaning & 4.31 & 3.77 & 0.53 & 0.99 & 0.78 & 0.49 & 0.54 \\
\hline Community centers & 3.93 & 3.41 & 0.81 & $1.12^{*}$ & 0.65 & 0.23 & 0.52 \\
\hline Parking & 4.58 & 4.11 & 0.29 & $0.95^{*}$ & 0.52 & 0.41 & 0.47 \\
\hline Greenery and trees & $5.1^{*}$ & $4.75^{*}$ & 0.45 & $0.63^{*}$ & 0.42 & 0.29 & 0.34 \\
\hline Walking facilities & $5.25^{*}$ & $4.96^{*}$ & 0.32 & $0.85^{*}$ & 0.46 & 0.33 & 0.29 \\
\hline Neighborhood associations & 5.01 & 4.88 & $-0.07^{*}$ & $0.8^{*}$ & 0.23 & 0.17 & 0.13 \\
\hline \multicolumn{8}{|l|}{$\begin{array}{l}{ }^{*} \mathrm{P}<0.05 \text {. } \\
{ }^{\dagger} \text { Number of households. } \\
{ }^{*} \text { Means of all neighborhoods. } \\
{ }^{8} \text { Residents were asked, "To wha }\end{array}$} \\
\hline
\end{tabular}

perception of neighborhood quality were walking (negative) and traffic safety (positive). For perceptions of neighborhood services, the largest and statistically significant changes are related to public art, biking facilities, and greenery and trees, with smaller, yet statistically significant differences in perceptions of traffic safety and walkability.

Additional neighborhood-specific analysis offers further insights into the spatial distribution of perceptions across the survey neighborhoods. The largest differences in perception were related to public art, biking facilities, street cleaning, and community centers. Positive trends were noted for neighborhoods 1 and 2 in all but one neighborhood services category: neighborhood associations. Neighborhoods 1 and 2 were also the only neighborhoods to document a negative change in perception in any neighborhood service. Conversely, neighborhoods 3 and 4, which received general program information and outreach efforts specific to the forthcoming green infrastructure, had the highest ratings for 13 of the 15 neighborhood quality indicators examined. In fact, all of the 15 categories showed positive trends, and all but one (public art) was above the overall average for the neighborhoods combined. Neighborhoods 5 and 6 (whose residents only received general program knowledge and limited educational materials) also showed positive trends for the 15 characteristics of neighborhood quality. Although these numbers were not as dramatic as those noted for neighborhoods 3 and 4, they were on average positive in all but four areas: traffic safety, attractiveness, public art, and biking facilities. The control neighborhoods showed negative trends for four of the seven categories: family friendly, healthy, sociable, and walkable. The greatest negative trend for the control neighborhood was in overall neighborhood health, which saw slightly more than a quarter- point reduction between surveys (Table 2). These results were further corroborated by t-test for assessing statistically significant difference in means.

\section{Predictors of stormwater stewardship}

I used only responses from the first survey to assess the predictors of stormwater stewardship. Responses from the second survey were not used because the regression model required a statistically robust number of respondents from each neighborhood, which the second survey did not contain. Results from the regression analysis of the first survey suggest that people who rated their neighborhood as favorable (higher average scores on questions of neighborhood quality and services) were more likely to become involved with stormwater management on public property. People who marked higher ratings for specific neighborhood characteristics were consistently located in places where new stormwater systems were not implemented, yet they had received high levels of outreach and education, such as in neighborhoods 3 and 4 .

Demographic and other factors were also associated with the likelihood of stewarding newly established stormwater facilities (Table 3). Respondents who identified their neighborhood as containing fewer parks and less green space were more likely to help to maintain stormwater facilities, perhaps because respondents viewed the new stormwater facilities as providing an increase of greenery, which was perceived as beneficial to neighborhood quality. Seven additional factors that helped to explain respondent willingness to maintain stowmwater facilities included: (1) spending less time the neighborhood, (2) prior involvement in environmental projects, (3) higher levels of formal education, (4) noninvolvement in religious organizations, (5) 
rating their community centers as unfavorable, (6) rating their neighborhood associations as favorable, and (7) perceiving that people can have a positive effect on their neighborhood. Although the predictive power (adducted $R^{2}$ ) is low, each of these eight factors was statistically significant and had a directional (positive or negative) coefficient.

Table 3. Self-identified significant factors that help to explain a respondent's likelihood of stewarding a public stormwater facility (all eight neighborhoods). Model adjusted $R^{2}=0.219$.

\begin{tabular}{lcc}
\hline \hline Variable & $\begin{array}{c}\text { Standardized } \\
\text { beta } \\
\text { coefficient }\end{array}$ & $P$ \\
\hline Constant & -0.195 & 0.002 \\
Number of years in the neighborhood & 0.218 & 0.001 \\
Prior involvement in environmental projects & 0.162 & 0.006 \\
Level of education & -0.127 & 0.023 \\
Involvement in religious organizations & -0.183 & 0.003 \\
Rating of local community centers & 0.206 & 0.001 \\
Rating of neighborhood associations & -0.150 & 0.018 \\
Rating of neighborhood greenery and trees & 0.120 & 0.044 \\
Perception of individual effect on & & \\
neighborhood & &
\end{tabular}

A final analysis employed two regression models to distinguish whether higher and lower income respondents self-identified different factors in terms of increasing their likelihood for stewarding stormwater facilities. Results suggest that the age of the respondent was the only factor in both the higher and lower income groups that determined a higher likelihood for stewarding stormwater facilities; that is, older respondents had lower stewardship potential (Table 4). Higher income residents were more likely to help maintain stormwater facilities if they had prior experience with environmental projects, frequently engaged with neighbors, and were not involved in religious organizations. Conversely, lower income residents were more likely to steward facilities if they had a higher education level, had higher ratings of their neighborhood association, and had lower ratings of local parks.

Overall, positive ratings of neighborhood biking and walking facilities, neighborhood associations, and greenery and trees were positively correlated with measures of interest in stormwater management. Furthermore, across both surveys, positive ratings of neighborhood friendliness, walkability, attractiveness, and safety from crime and traffic were positively correlated with measures of interest in stormwater management. These factors are likely mediated by income because those with an annual income $>\$ 75,000$ had different factors that helped to explain their interest in stewarding stormwater facilities than did those with a lower annual income. These results suggest that a stormwater management strategy using green infrastructure likely will be supported in areas where general perceptions of neighborhood quality are favorable. However, in locations where stormwater facilities were recently implemented, respondents were less favorable toward participation in stewardship activities.

\section{DISCUSSION}

The results suggest a number of key findings that may help to inform the current understanding of the likelihood of changing human behavior in a changing landscape. In the case of neighborhood change and human behavior, the results suggest that support for maintaining new stormwater facilities may be mediated by pre-existing conditions that might interact with biophysical changes either to attract or to obstruct public participation in stewardship efforts. At the individual level, higher levels of education, better quality neighborhood associations, and perceptions of lower quality parks were directly correlated with an interest in stewardship activities. Aside from the age of the respondent, these factors differed depending on annual income. At the societal level, those who engaged with neighbors more frequently identified a higher propensity to steward stormwater facilities. Because I assumed that stormwater stewardship actions were nonexistent because of the lack of such stewardship activities prior to the installation of such facilities, I was not able to decipher whether civic involvement (e.g., engaging with neighbors) induced interest in stormwater stewardship interests or vice versa. At the same time, these results are consistent with experiential and transformative learning theory, which supports the importance of daily interactions, in this case with visible stormwater systems, as a key component for community action (Cantrill and Senecah 2001, Uzzell et al. 2002).

Table 4 Self-identified significant factors that help to explain a respondent's likelihood of stewarding public stormwater facilities based on lower $(<\$ 75,000$ USD) vs. higher ( $>\$ 75,000$ USD) annual income.

\begin{tabular}{|c|c|c|c|}
\hline $\begin{array}{l}\text { Income } \\
\text { Variable }\end{array}$ & $\begin{array}{r}\text { Standardized } \\
\text { beta } \\
\text { coefficient }\end{array}$ & $t$ & $P$ \\
\hline \multicolumn{4}{|l|}{ Lower $^{\dagger}$} \\
\hline Constant & & 1.988 & 0.049 \\
\hline Level of education & 0.291 & 3.830 & $<0.0001$ \\
\hline Rating of neighborhood association & 0.367 & 4.376 & $<0.0001$ \\
\hline Rating of local parks & -0.259 & -3.118 & 0.002 \\
\hline Age of respondent & -0.220 & -2.938 & 0.004 \\
\hline \multicolumn{4}{|l|}{ Higher ${ }^{*}$} \\
\hline Constant & & 3.770 & $<0.0001$ \\
\hline $\begin{array}{l}\text { Prior involement with environmental } \\
\text { projects }\end{array}$ & 0.296 & 3.697 & $<0.0001$ \\
\hline $\begin{array}{l}\text { Level of involvement with religious } \\
\text { organizations }\end{array}$ & -0.293 & -3.623 & $<0.0001$ \\
\hline $\begin{array}{l}\text { Frequency of conversation with } \\
\text { neighbors }\end{array}$ & 0.213 & 2.623 & 0.010 \\
\hline Age of respondent & -0.203 & -2.502 & 0.014 \\
\hline
\end{tabular}

The results also provide insights into the coupling of natural and human systems as they affect stormwater management in cities. First, a change in the biophysical landscape led to several quantifiable changes in perceptions of neighborhood characteristics. These changes suggest a feedback mechanism that links localized changes in the physical infrastructure with perceptions that can, in turn, affect the likelihood of stewardship behavior. The localized changes, often visible and occurring in the public right of way, precipitated changes in perception that can be discerned from the control groups. While these differences varied by neighborhood, results from paired t-tests suggest that neighborhoods that had extensive physical changes saw, on the 
whole, statistically significant differences in perceptions between the two surveys. Across both survey years, the control groups did not reflect the extent of changes seen in the other neighborhoods, except for the statistically significant difference in perceptions of neighborhood bicycle facilities. I posit that the difference in perception of bicycle facilities for the control groups was because of the creation of extensive bicycle boulevards, signage, and other facilities during the study period.

Second, the varied level of physical change in each neighborhood directly corresponded to the emerging acceptance of new facilities. Survey responses indicate that the acceptance of new public neighborhood stormwater facilities emerged from greater understanding of the role of these systems in the urban landscape. This emergent property (of perception) seems to be directly proportional to the stage of physical change occurring in the neighborhood. For example, respondents who had not seen changes (i.e., neighborhoods 3-6) but expected changes to occur in the near future based on outreach and education materials seemed to anticipate an imminent physical change suggestive of an improvement in existing conditions. The fact that differences in perceptions became less statically significant with decreasing outreach and education materials suggests that city engagement efforts can affect the likelihood of public acceptance of new green facilities. An equally compelling interpretation is that those anticipating neighborhood change and those who have been informed about upcoming improvements are in fact responding to an improvement that is yet to be realized, resulting in a statistically significant positive response across many of the categories.

Finally, time lags are apparent in the stewardship of these facilities. The results from both surveys suggest that residents had a greater interest in stewardship in neighborhoods with existing facilities. Regardless of the specific stage of development or outreach, individual respondents were more likely to consider stewarding these facilities when they had seen or lived near a stormwater facility. In some cases, stormwater stewardship groups had emerged to engage the stewardship of the facilities. In contrast, in areas where facilities were recently installed, fewer respondents overall expressed an interest in stewardship behaviors. The variation in stewardship behavior suggests that a localized social process might create a time lag of acceptance and behavioral response. Although the survey results do not allow me to identify a specific mechanism that might explain such a time lag, I speculate that an early familiarity and understanding of the facilities, their maintenance, and their integration into the neighborhood may foster their acceptance and care.

There are numerous changes occurring in the T2R area, some of which are related to the T2R stormwater program and others to changes occurring throughout the city, including the expansion of bicycling infrastructure, roadways, and other infrastructure. Whether the specific differences in perception observed here may be attributable solely to the creation of the T2R stormwater program or to other external factors remains to be seen; however, the discrete spatial and temporal changes to specific neighborhoods suggest that the $\mathrm{T} 2 \mathrm{R}$ has played a role in changing neighborhood perceptions. Additionally, the initial stages of installing green infrastructure in select neighborhoods can create a nuisance and other undesirable effects that may be responsible for the observed negative trends. These include noise, dust, traffic disruptions, sparse landscaping, undeveloped trees and plants, and construction hazards. Future studies are needed to understand whether and how these short-term negative affects dissipate, and to what extent perceptions change as the green infrastructure matures in each neighborhood.

\section{CONCLUSIONS}

The understanding of ways to engage the public in environmental stewardship has a long and complex history. Although my survey results suggest a combination of individual and social factors that increase the likelihood of stewarding neighborhood stormwater facilities, an actual shift in behavior may require further engagement of residents. For example, research on environmental behavior change shows that one act alone, for example, the simple observation of a physical object (e.g., new stormwater facility), holds less potential for change in environmentally directed behavior compared to active engagement (Vaske and Kobrin 2001, Kaplan and Kaplan 2005, Ryan 2005). Stern (2000) also identified the need for multiple stimuli to induce behavior change, which in this case may require the presence of a physical object, education and outreach materials, and stewardship programs that demonstrate ways of correctly stewarding the new stormwater facilities. Such active engagement, which involves learning by doing rather than simple observation, may be of greater significance to learning than is passive observation (Loeber et al. 2007).

In terms of the coupling of human and natural systems that the neighborhood change reflects, I described linkages between the biophysical landscape, with specific emphasis on the framing and perceptions of landscapes and commensurate institutional or social dimensions that might affect behavior. I found that these linkages do exist and that the behaviors of residents correspond to perceptions of environmental need related to new green infrastructure. Feedbacks, emergent properties, and time lags reflect dimensions of a CHANS framework described in earlier research (see for example, Liu et al. 2007). The results also illustrate a lack of behavioral response among some respondents; that is, not all respondents were similarly willing to change their behavior and steward the facilities regardless of the biophysical change occurring in their neighborhoods. However, the fact that physical changes can motivate social behavior is consistent with other research on urban environmental stewardship (Kudryavtsev et al. 2012, Tidball and Krasny 2012), and this observation may help to frame better approaches to stormwater (or other ecological) challenges facing cities.

One aspect of this research that requires further study is the role of stewardship (or other behaviors) on the structure and function of these facilities. Because these facilities are designed aboveground and convey stormwater away from the underground pipe infrastructure, they are susceptible to degradation, vandalism, or neglect. Other research in the Pacific Northwest suggests that stormwater facilities that go unmaintained can stop functioning, leading to hydrological challenges, including flooding and pollutant accumulation (Booth and Jackson 1997, Dietz 2007). As a result, without adequate maintenance or stewardship of these facilities, regional water quality and the hydrological regime could be compromised. Whether the actions of citizens will be sufficient to ensure the adequate functioning 
of these facilities and to improve the provision of ecosystem services remains to be seen. As these facilities mature, future research will need to assess the roles of policies, behaviors, and endogenous factors in addressing the pressing challenges facing cities.

The creation of aboveground green infrastructure to address problems of urban stormwater systems represents an attempt to replicate the natural processes of infiltration that existed predevelopment. As such, these intermediate and replacement services require modifications of the built infrastructure, artificially replacing services lost from the modification of natural systems. Although forests, wetlands, and grasslands have been well studied, few studies have evaluated the types, extent, or quality of services in human-dominated landscapes, which will be increasingly vulnerable with the emerging management challenges under new scenarios of climate change and variability. An ability to further explicate the mechanisms linking humans and the environment will be essential to addressing the pressing environmental challenges of climate change. In the coming decades, related research will also be needed to enable those who manage human-dominated landscapes to respond effectively to increasing uncertainty using infrastructure systems that are embedded within communities that can attend to their care.

Responses to this article can be read online at: http://www.ecologyandsociety.org/issues/responses. $\mathrm{php} / 7736$

\section{Acknowledgments:}

I am grateful to the anonymous reviewers and editors who provided valuable insights on this paper. For financial assistance, I acknowledge the National Science Foundation for support of the Urban Long-Term Research Area-Exploratory (Project \#0948983).

\section{LITERATURE CITED}

Ajzen, I., and M. Fishbein. 1980. Understanding attitudes and predicting social behavior. Prentice Hall, Englewood Cliffs, New Jersey, USA.

Alberti, M. 2008. Advances in urban ecology: integrating humans and ecological processes in urban ecosystems. Springer, New York, New York, USA. http://dx.doi.org/10.1007/978-0-387-75510-6

Alberti, M., J. M. Marzluff, E. Shulenberger, G. Bradley, C. Ryan, and C. Zumbrunnen. 2003. Integrating humans into ecology: opportunities and challenges for studying urban ecosystems. BioScience 53(12):1169-1179. http://dx.doi.org/10.1641/0006-3568 (2003)053[1169:IHIEOA]2.0.CO;2

Bassett, E., and V. Shandas. 2010. Innovation and climate action planning: perspectives from municipal plans. Journal of the American Planning Association 76(4):435-450. http://dx.doi. org/10.1080/01944363.2010.509703

Beatley, T. 2011. Biophilic cities: integrating nature into urban design and planning. Island Press, Washington, D.C., USA. http:// dx.doi.org/10.5822/978-1-59726-986-5
Blake, J. 1999. Overcoming the 'value-action gap' in environmental policy: tensions between national policy and local experience. Local Environment: the International Journal of Justice and Sustainability 4(3):257-278. http://dx.doi. org/10.1080/13549839908725599

Bonaiuto, M., A. Aiello, M. Perugini, M. Bonnes, and A. P. Ercolani. 1999. Multidimensional perception of residential environment quality and neighbourhood attachment in the urban environment. Journal of Environmental Psychology 19(4):331-352. http://dx.doi.org/10.1006/jevp.1999.0138

Booth, D. B., and C. R. Jackson. 1997. Urbanization of aquatic systems: degradation thresholds, stormwater detention, and the limits of mitigation. Journal of American Water Resources Association 33(5):1077-1090. http://dx.doi.org/10.1111/j.1752-1688.1997. tb04126.x

Brody, S. D., S. Zahran, H. Grover, and A. Vedlitz. 2008. A spatial analysis of local climate change policy in the United States: risk, stress, and opportunity. Landscape and Urban Planning 87 (1):33-41. http://dx.doi.org/10.1016/j.landurbplan.2008.04.003

Brown, B., D. D. Perkins, and G. Brown. 2003. Place attachment in a revitalizing neighborhood: individual and block levels of analysis. Journal of Environmental Psychology 23(3):259-271. http://dx.doi.org/10.1016/S0272-4944(02)00117-2

Cantrill, J. G., and S. L. Senecah. 2001. Using the 'sense of selfin-place' construct in the context of environmental policy-making and landscape planning. Environment Science and Policy 4 (4-5):185-203. http://dx.doi.org/10.1016/s1462-9011(01)00023-5

Cao, X., P. L. Mokhtarian, and S. L. Handy. 2007. Do changes in neighborhood characteristics lead to changes in travel behavior? A structural equations modeling approach. Transportation 34(5):535-556. http://dx.doi.org/10.1007/s11116-007-9132$\underline{\mathrm{x}}$

Chapin, S. F. III, S. R. Carpenter, G. P. Kofinas, C. Folke, N. Abel, W. C. Clark, P. Olsson, D. M. Stafford Smith, B. Walker, O. R. Young, F. Berkes, R. Biggs, J. M. Grove, R. L. Naylor, E. Pinkerton, W. Steffen, and F. J. Swanson. 2010. Ecosystem stewardship: sustainability strategies for a rapidly changing planet. Trends in Ecology and Evolution 25(4):241-249. http://dx. doi.org/10.1016/j.tree.2009.10.008

Chavis, D. M., and A. Wandersman. 1990. Sense of community in the urban environment: a catalyst for participation and community development. American Journal of Community Psychology 18(1):55-81. http://dx.doi.org/10.1007/BF00922689

City of Portland. 2007. Green streets: cross-bureau team report: phase 2. City of Portland, Portland, Oregon, USA. [online] URL: https://www.portlandoregon.gov/shared/cfm/image.cfm?id=153974.

City of Portland. 2010. Stormwater management facility monitoring report. City of Portland, Portland, Oregon, USA. [online] URL: http://www.portlandoregon.gov/bes/article/432507.

City of Portland. 2013. Integrating stormwater into the built environment. City of Portland, Portland, Oregon, USA. [online] URL: http://www.portlandoregon.gov/bes/article/53558.

Connolly, J. T. J., E. S. Svendsen, D. R. Fisher, and L. K. Campbell. 2014. Networked governance and the management of ecosystem 
services: the case of urban environmental stewarship in New York City. Ecosystems Services 10:187-194. http://dx.doi.org/10.1016/ j.ecoser.2014.08.005

Dale, A. 2009. In praise of mundane nature: the unsung nature in alleyways and backyards plays an important - and undervalued - role in urban lives. Alternatives Journal 35(2):32-35.

Dietz, M. E. 2007. Low impact development practices: a review of current research and recommendations for future directions. Water, Air, and Soil Pollution 186(1-4):351-363. http://dx.doi. org/10.1007/s11270-007-9484-Z

Dillman, D. A. 2007. Mail and internet surveys: the tailored design method. Second edition. Wiley, Hoboken, New Jersey, USA.

Dillman, D. A., J. D. Smyth, and L. M. Christian. 2014. Internet, phone, mail, and mixed-mode surveys: the tailored design method. Fourth edition. Wiley, Hoboken, New Jersey, USA.

Dulière, V., Y. Zhang, and E. P. Salathé Jr. 2011. Extreme precipitation and temperature over the U.S. Pacific Northwest: a comparison between observations, reanalysis data, and regional models. Journal of Climate 24(7):1950-1964. http://dx.doi. org/10.1175/2010JCLI3224.1

Fishbein, M., and I. Ajzen. 1975. Belief, attitude, intention, and behavior: an introduction to theory and research. Addison-Wesley, Reading, Massachusetts, USA.

Furlong, K. 2010. Small technologies, big change: rethinking infrastructure through STS and geography. Progress in Human Geography 35(4):460-482. http://dx.doi.org/10.1177/0309132510380488

Grimm, N. B., and C. L. Redman. 2004. Approaches to the study of urban ecosystems: the case of central Arizona-Phoenix. Urban Ecosystems 7(3):199-213. http://dx.doi.org/10.1023/B: UECO.0000044036.59953.a1

Hough, M. 2004. Cities and natural process: a basis for sustainability. Second edition. Routledge, London, UK.

Jarvis, P. 2009. Learning to be a person in society: learning to be me. Pages 21-34 in K. Illeris, editor. Contemporary theories of learning: learning theorists...in their own words. Routledge, London, UK.

Kaplan, R., and S. Kaplan. 2005. Preference, restoration, and meaningful action in the context of nearby nature. Pages 271-298 in P. F. Barlett, editor. Urban place: reconnecting with the natural world. MIT Press, Cambridge, Massachusetts, USA.

Kollmuss, A., and J. Agyeman. 2002. Mind the gap: Why do people act environmentally and what are the barriers to proenvironmental behavior? Environmental Education Research 8 (3):239-260. http://dx.doi.org/10.1080/13504620220145401

Kreutzwiser, R., R. de Loë, K. Imgrund, M. J. Conboy, H. Simpson, and R. Plummer. 2011. Understanding stewardship behavior: factors facilitating and constraining private water well stewardship. Journal of Environmental Management 92 (4):1104-1114. http://dx.doi.org/10.1016/j.jenvman.2010.11.017

Kudryavtsev, A., R. C. Stedman, and M. E. Krasny. 2012. Sense of place in environmental education. Environmental Education Research 18(2):229-250. http://dx.doi.org/10.1080/13504622.2011.609615
Liu, J., T. Dietz, S. R. Carpenter, M. Alberti, C. Folke, E. Moran, A. N. Pell, P. Deadman, T. Kratz, J. Lubchenco, E. Ostrom, Z. Ouyang, W. Provencher, C. L. Redman, S. H. Schneider, and W. W. Taylor. 2007. Complexity of coupled human and natural systems. Science 317:1513-1516. http://dx.doi.org/10.1126/ science. 1144004

Loeber, A., B. van Mierlo, J. Grin, and C. Leeuwis. 2007. The practical value of theory: conceptualising learning in the pursuit of a sustainable development. Pages 83-98 in A. E. J. Wals, editor. Social learning towards a sustainable world: principles, perspectives, and praxis. Wageningen Academic Publishers, Wageningen, The Netherlands.

MacLeod, G., and M. Goodwin. 1999. Space, scale and state strategy: rethinking urban and regional governance. Progress in Human Geography 23(4):503-527. http://dx.doi.org/10.1191/030$\underline{913299669861026}$

Mezirow, J. 1997. Transformative learning: theory to practice. New Directions for Adult and Continuing Education 74:5-12. http:// dx.doi.org/10.1002/ace.7401

National Research Council. 2009. Urban stormwater management in the United States. National Academies Press, Washington, D. C., USA.

Pickett, S. T. A., M. L. Cadenasso, M. J. McDonnell, and W. R. Burch Jr. 2009. Frameworks for urban ecosystem studies: gradients, patch dynamics and the human ecosystem in the New York metropolitan area and Baltimore, USA. Pages 25-50 in M. J. McDonnell, A. K. Hahs, and J. Breuste, editors. Ecology of cities and towns: a comparative approach. Cambridge University Press, Cambridge, UK. http://dx.doi.org/10.1017/cbo9780511609763.004

Reckwitz, A. 2002. Toward a theory of social practices: a development in culturalist theorizing. European Journal of Social Theory 5(2):243-263.

Ryan, R. L. 2005. Exploring the effects of environmental experience on attachment to urban natural areas. Environment and Behavior 37(1):3-42. http://dx.doi.org/10.1177/0013916504264147

Shandas, V., J. A. Yeakley, E. Granek, D. Ervin, V. Dujon, and H. Chang. 2014. Characterizing urban ecosystem services: integrating the biophysical and social dimensions of humandominated landscapes. Pages 295-312 in K. N. Ninan, editor. Valuing ecosystem services: methodological issues and case studies. Edward Elgar, Cheltenham, UK.

Shove, E. 2010. Beyond the ABC: climate change policy and theories of social change. Environment and Planning A 42 (6):1273-1285. http://dx.doi.org/10.1068/a42282

Stern, P. C. 2000. Psychology and the science of humanenvironment interactions. American Psychologist 55(5):523-530. http://dx.doi.org/10.1037/0003-066X.55.5.523

Tidball, K. G., and M. E. Krasny. 2012. A role for citizen science in disaster and conflict recovery and resilience. Pages 226-234 in J. L. Dickinson and R. Bonney, editors. Citizen science: public participation in environmental research. Cornell University Press, Cornell, New York, USA.

United Nations. 2008. World population prospects: the 2008 revision: highlights. Department of Economic and Social Affairs, 
United Nations, New York, New York, USA. [online] URL: http://www.un.org./esa/population/publications/wpp2008/ wpp2008 highlights.pdf.

United States Environmental Protection Agency. 2007. Reducing stormwater costs through low impact development ( LID) strategies and practices. EPA 841-F-07-006. United States Environmental Protection Agency, Washington, D.C., USA. [online] URL: http://water.epa.gov/polwaste/green/upload/2008 0102 NPS 1id costs 07 uments reducingstormwatercosts-2.pdf.

Uzzell, D., E. Pol, and D. Badenas. 2002. Place identification, social cohesion, and environmental sustainability. Environment and Behavior 34(1):26-53. http://dx.doi.org/10.1177/0013916502$\underline{034001003}$

Vaske, J. J., and K. C. Kobrin. 2001. Place attachment and environmentally responsible behavior. Journal of Environmental Education 32(4):16-21. http://dx.doi.org/10.1080/00958960109598658

Vitousek, P. M., H. A. Mooney, J. Lubchenco, and J. M. Melillo. 1997. Human domination of Earth's ecosystems. Science 277:494-499. http://dx.doi.org/10.1126/science.277.5325.494

Wall Street Journal. 2012. U.S. data skewed by storm's effect. Wall Street Journal November 11, 2012.

Wheeler, S. M. 2008. State and municipal climate change plans: the first generation. Journal of the American Planning Association 74(4):481-496. http://dx.doi.org/10.1080/01944360802377973

Yin, R. K. 2003. Case study research: design and methods. Third edition. Sage, Thousand Oaks, California, USA. 


\section{SE Portland Neighborhood Survey}

\section{Why respond to this survey?}

Portland State University and the City of Portland Bureau of Environmental Services are conducting this survey to evaluate outreach work for the Tabor to the River: Brooklyn Creek Basin Program. Your input is valuable and will help us improve programs and projects in your community over the coming years.

The survey will take about 15 minutes.

You are a one of a select few to receive this survey, and when we receive your response we'll enter your name in a drawing to win one of 21 prizes. The grand prize is a tour of the East Side Big Pipe tunnel. To notify you if you win a prize, we need your phone number or email address. We won't contact you for any other reason, unless you are interested in working with us further on this study.

Thank you for your time and consideration.

\section{Background}

The Brooklyn Creek Basin extends from Mt. Tabor to the Willamette River between SE Hawthorne and SE Powell boulevards. Some sewer pipes in the basin are nearly 100 years old, and many are too small to handle large volumes of stormwater runoff during heavy rain, which causes street flooding and sewer backups into basements.

The Tabor to the River: Brooklyn Creek Basin Program combines innovative stormwater management techniques with sewer improvements to stop sewer backups, manage stormwater more naturally, and to restore watershed health.

The program includes constructing 500 green stormwater management facilities, planting 4,000 street trees, removing invasive vegetation from natural areas and encouraging individual and community actions to improve watershed health.

\section{How do green stormwater facilities and trees improve watershed health?}

- They filter pollutants from the stormwater.

- They keep stormwater out of the combined sewer system.

- They slow stormwater flow and allow water to soak into the soil to replenish groundwater supplies.

\section{How can communities improve watershed health?}

People taking individual actions and working together can help improve watershed health. Plant a tree in your yard, use native plants in your landscaping, learn about using alternatives to pesticides and fertilizers in your yard. Improving watershed health improves neighborhood livability.

\section{A. In this section, we'd like to find out how much you've heard about the city's stormwater projects.}

1) Before taking this survey, were you aware of stormwater-related projects planned in the Brooklyn Creek Basin?

$\square$ Yes $\quad \square$ No (If no, skip to \#4) $\quad \square$ Not Sure

\section{2) If yes, where did you hear about these projects? (Check all that apply)}
A. $\square$ Letter about the stormwater projects in your neighborhood
B. $\square$ Tabor to the River newsletter
C. $\square$ Tabor to the River table at a community event
D. $\square$ Community meeting or workshop
E. Tours: $\square$ bike $\square$ boat $\square$ walking
F. $\square$ Survey other than this one
G. $\square$ Internet (website or email) 
H. $\square$ Friends, family, neighbors

I. $\square$ Community groups/neighborhood association

Which ones:

J. $\square$ Other communications:

Which one of the above methods (A-J) was most informative about stormwater/watershed health projects in your area? (Choose one) $\quad \square \mathrm{A} \quad \square \mathrm{B} \quad \square \mathrm{C} \quad \square \mathrm{D} \quad \square \mathrm{E} \quad \square \mathrm{F} \quad \square \mathrm{G} \quad \square \mathrm{H} \quad \square \mathrm{I} \quad \square \mathrm{J}$

3) Did the information you received about these projects (question \#2 above) affect what you do on your own property?

$\square$ Yes: How?
$\square$ No
$\square$ Not Sure

4) Do you have stormwater problems on your property?

$\square$ Yes: What are they?
$\square$ No
$\square$ Not Sure

5) Where do you look for information about managing stormwater on your property? (Check all that apply)
A. $\square$ Internet
B. $\square$ Regional Newspaper
C. $\square$ Neighborhood Newspaper
D. $\square$ City-sponsored mailings
F. $\square$ Friends, family, neighbors
G. $\square$ Technical experts
H. $\square$ Television
I. $\square$ Other:
J. $\square$ I don't look for information about stormwater management

\section{B. In this section, we'd like to hear about your neighborhood.}

1) To what extent do you believe your neighborhood is.....?

Attractive

Safe (with respect to crime)

Safe (with respect to traffic)

Walkable

Friendly/Social

Family Friendly

Healthy

$$
\text { Not at all }
$$

$\begin{array}{llllll}1 & 2 & 3 & 4 & 5 & 6 \\ 1 & 2 & 3 & 4 & 5 & 6 \\ 1 & 2 & 3 & 4 & 5 & 6 \\ 1 & 2 & 3 & 4 & 5 & 6 \\ 1 & 2 & 3 & 4 & 5 & 6 \\ 1 & 2 & 3 & 4 & 5 & 6 \\ 1 & 2 & 3 & 4 & 5 & 6\end{array}$

No Opinion
NO
NO
NO
NO
NO
NO
NO

No Opinion

NO

$\mathrm{NO}$

NO

NO

2) Rate how well you believe your neighborhood provides the following: 
Neighborhood Associations

$\begin{array}{llllllll}1 & 2 & 3 & 4 & 5 & 6 & \mathrm{NO}\end{array}$

Parking

$\begin{array}{llllll}1 & 2 & 3 & 4 & 5 & 6\end{array}$

$\begin{array}{lllllll}\text { Walking Facilities (e.g. sidewalks, safe crossings)1 } & 2 & 3 & 4 & 5 & 6 & \text { NO }\end{array}$

$\begin{array}{llllllll}\text { Biking facilities (e.g. bike parking, paths) } & 1 & 2 & 3 & 4 & 5 & 6 & \text { NO }\end{array}$

$\begin{array}{llllllll}\text { Street Cleaning Services } & 1 & 2 & 3 & 4 & 5 & 6 & \text { NO }\end{array}$

$\begin{array}{llllllll}\text { Greenery/Trees } & 1 & 2 & 3 & 4 & 5 & 6 & \text { NO }\end{array}$

$\begin{array}{llllllll}\text { Public Art } & 1 & 2 & 3 & 4 & 5 & 6 & \text { NO }\end{array}$

3) How many neighbors on your block do you know by first name?
$\square$ All neighbors
$\square$ A few neighbors
$\square$ One or two neighbors
$\square$ None

\section{4) How would you say most people living in your area feel about the neighborhood?}

No one cares about the neighborhood----Everyone cares about the neighborhood No

$$
\begin{array}{llllll}
1 & 2 & 3 & 4 & 5 & 6
\end{array}
$$

Opinion

NO

5) How much impact do you think you can have in making your neighborhood a better place to live?

No impact at all------------------Big Impact

$\begin{array}{llllll}1 & 2 & 3 & 4 & 5 & 6\end{array}$

NO No Opinion

In what ways can you have an impact or what keeps you from making changes in your neighborhood?

\section{6) How often do you...... (Check only one box)}

Attend public or town meetings?

$\square$ Never/Very Rarely $\square$ A few times per year $\square$ Monthly $\square$ Weekly or more

Attend neighborhood/community meetings?

$\square$ Never/Very Rarely $\square$ A few times per year $\square$ Monthly $\square$ Weekly or more

Attend any club or organizational meetings?

$\square$ Never/Very Rarely $\square$ A few times per year $\square$ Monthly $\square$ Weekly or more

Attend educational workshops?

$\square$ Never/Very Rarely $\square$ A few times per year $\square$ Monthly $\square$ Weekly or more

Work on community projects?

$\square$ Never/Very Rarely $\square$ A few times per year $\square$ Monthly $\square$ Weekly or more

Share conversations with neighbors?

$\square$ Never/Very Rarely $\square$ A few times per year $\square$ Monthly $\square$ Weekly or more

Share things or time with neighbors (food, tools, help with tasks, etc.)?

$\square$ Never/Very Rarely $\square$ A few times per year $\square$ Monthly $\square$ Weekly or more 
Have neighbors over to your home?

$\square$ Never/Very Rarely $\square$ A few times per year $\square$ Monthly $\square$ Weekly or more

Take a walk in your neighborhood?

$\square$ Never/Very Rarely $\square$ A few times per year $\square$ Monthly $\square$ Weekly or more

Volunteer?

$\square$ Never/Very Rarely $\quad \square$ A few times per year $\quad \square$ Monthly $\square$ Weekly or more

5) Have you been involved in any of the following in the past 12 months? (Check all that apply)

$\square$ Neighborhood or community group

$\square$ Adult sports or cultural group

$\square$ School group

$\square$ Religious organization

$\square$ Sports or cultural program for children

$\square$ Environmental project (e.g. tree planting, ivy pull)

\section{In this section, we'd like to hear your opinions about your yard and property.}

1) Of the following stormwater management strategies, how likely are you to use each on your property? (Not likely $=1$, very likely $=6$, if you're already using it, or don't know what it is, check the box under that heading; please feel free to provide us with comments about how you are using these-attach pages as needed)

$$
\begin{gathered}
\text { Not likely ---------------Very likely Already Don't know Comments } \\
\text { Using what this is }
\end{gathered}
$$

\begin{tabular}{|c|c|c|c|c|c|c|c|}
\hline Bioswales & 1 & 2 & 3 & 4 & 5 & 6 & $\square$ \\
\hline \multicolumn{2}{|c|}{ Downspout Disconnection1 } & 2 & 3 & 4 & 5 & 6 & $\square$ \\
\hline Ecoroofs (green roofs) & 1 & 2 & 3 & 4 & 5 & 6 & $\square$ \\
\hline \multicolumn{2}{|c|}{ Rain barrels to reuse water 1} & 2 & 3 & 4 & 5 & 6 & $\square$ \\
\hline Rain gardens & 1 & 2 & 3 & 4 & 5 & 6 & $\square$ \\
\hline Removal of paved areas & & 2 & 3 & 4 & 5 & 6 & 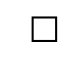 \\
\hline Removal of lawn & 1 & 2 & 3 & 4 & 5 & 6 & $\square$ \\
\hline Trees (plant and/or pres & erve) 1 & 2 & 3 & 4 & 5 & 6 & 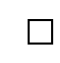 \\
\hline Natural gardening/natur & escaping & & 2 & 3 & 4 & 5 & \\
\hline Drywell or soakage tren & ich 1 & 2 & 3 & 4 & 5 & 6 & \\
\hline Porous pavement or pav & ers 1 & 2 & 3 & 4 & 5 & 6 & \\
\hline Infiltration Planter & 1 & 2 & 3 & 4 & 5 & 6 & $\sqcup$ \\
\hline Flow-through Planter & 1 & 2 & 3 & 4 & 5 & 6 & \\
\hline
\end{tabular}

2) What would be most helpful in installing any of the above stormwater strategies? (Choose one)
$\square$ Financial assistance
$\square$ Help with maintenance
$\square$ More time
$\square$ More information about benefits 
$\square$ More attractive results

3) How much time would you be willing to spend maintaining vegetation on your street?
$\square$ None
$\square$ 1-3 hours per month
$\square$ 1-3 hours every few months
$\square$ 1-3 hours per year

5) What would encourage you to get more involved with stormwater management in your neighborhood or on your property? (Check your top three)

$\square$ Seeing my neighbors taking similar actions

$\square$ Feeling like I could choose the plants in city-owned stormwater facilities

$\square$ Better understanding of how my actions benefit watershed and community health

$\square$ Adopting a stormwater facility and being responsible for its care

$\square$ Rotating care responsibilities with neighbors

$\square$ Having the city install a green street in front of my property

$\square$ Being provided a how-to guide or in-person instruction

$\square$ I am already involved, what else can I do?

$\square$ Other:

6) I would like to know more about... (Check your top five)

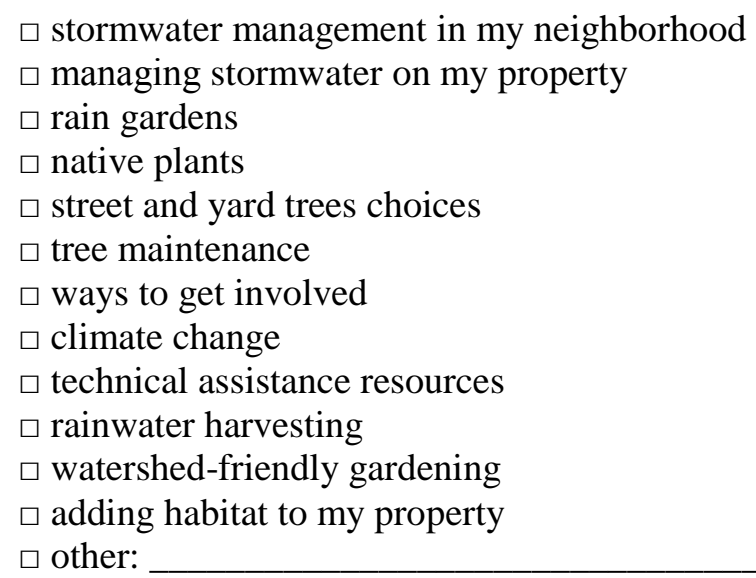

\section{7) Please tell us how you feel about the following statements:}

(1 = Strongly disagree, $6=$ strongly agree, $N A=$ not applicable $)$

I would take a course on managing stormwater

I am interested in learning more about caring for my trees

I would like more vegetation on my street

I would be willing to help maintain a stormwater facility

I am aware of city projects before they happen in my neighborhood

The city makes an effort to let me know the need for a project

I want to help with stormwater projects in my neighborhood

I am interested in having more neighborhood events or activities

\begin{tabular}{cccccccc}
$\begin{array}{c}\text { Strongly } \\
\text { disagree }\end{array}$ & \multicolumn{4}{c}{$\begin{array}{c}\text { Strongly } \\
\text { agree }\end{array}$} & $\begin{array}{c}\text { Not } \\
\text { applicable }\end{array}$ \\
1 & 2 & 3 & 4 & 5 & 6 & NA \\
1 & 2 & 3 & 4 & 5 & 6 & NA \\
1 & 2 & 3 & 4 & 5 & 6 & NA \\
1 & 2 & 3 & 4 & 5 & 6 & NA \\
1 & 2 & 3 & 4 & 5 & 6 & NA \\
1 & 2 & 3 & 4 & 5 & 6 & NA \\
1 & 2 & 3 & 4 & 5 & 6 & NA \\
1 & 2 & 3 & 4 & 5 & 6 & NA
\end{tabular}


Can we follow up with you to get a little more feedback about your neighborhood?

$\square$ Yes (Please provide a phone number or email address):

Please share any additional comments you have with us:

To be entered in the drawing, please supply us with a phone number and/or valid e-mail address

This section asks a few demographic questions for our study. This information will not be tracked to you individually - please see cover sheet for more information.

1) In which range does your age fit?
$\square$ Under 18
$\square 45-54$
$\square$ 18-24
$\square 55-64$
$\square 25-34$
$\square 65+$
$\square 35-44$

2) Is this a home or business address?

$\square$ Home $\quad \square$ Business

$\square$ Other:

3) Do you rent or own your home/business space:
Home:
Business: $\square$ Rent
$\square$ Own
$\square$ Own

4) What is your highest level of education? (Choose only one)
$\square$ Less than High School
$\square$ High School Degree
$\square$ Associate's Degree
$\square$ Some College
$\square$ Bachelor's Degree
$\square$ Post-Graduate Degree

5) What was your approximate household income in 2008 before taxes? (Choose only one)
$\square$ Less than $\$ 15,000$
$\square \$ 15,000-24,999$
$\square \$ 50,000-74,999$
$\square \$ 25,000-34,999$
$\square \$ 75,000-99,999$
$\square \$ 35,000-49,999$
$\square \$ 100,000-150,000$
$\square$ Over $\$ 150,000$

6) In what kind of building do you live?

$\square$ Detached house/business

$\square$ Attached house or townhouse

$\square$ Multi-house/business (ex: apartment/multi-use complex)

$\square$ Other:

7) How long have you lived in your current residence? Years Months

Thank you for your time and contributions to this survey. Your responses will make a difference. Remember, if you want to be entered into the drawing, provide us a way to get in touch with you. (above) 